\title{
History of Science
}

the only review of literature and research in the history of science. medicine and technology in its intellectual and social context

\section{2-1984}

A special post-free offer to new subscribers valid until 31 December 1985

\section{Volumes 1-22 hardbound, US \$400/ $\$ 225$}

From Science History Publications Ltd, Halfpenny Furze, Mill Lane, Chalfont St Giles, Bucks HP8 4NR, England.

History of Science is published quarterly in issues of about 112 pages.

Volume 23 (1985) will include

JAMES A. SECORD Newton in the Nursery: Tom Telescope and the Philosophy of Tops and Balls, 1761-1838

PATRICK CURRY Revisions of Magic and Science

WILliam R. WOODWARD Committed History and Philosophy of the Social Sciences in the Two Germanies

FRANK A. J. L. JAMES The Creation of a Victorian Myth: The Historiography of Spectroscopy

PNINA ABIR-AM Themes, Genres and Orders of Legitimation in the Consolidation of New, Scientific Disciplines

JAMES MCGEACHIE Darwin and George Eliot: Plotting and Organicism

The Annual Subscription is US $\mathbf{\$ 7 7 . 0 0}$ post-free in the Americas and

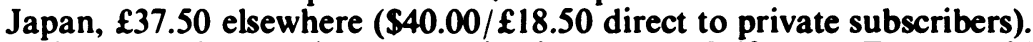
Write to: Science History Publications Ltd, Halfpenny Furze, Mill Lane, Chalfont St Giles, Bucks HP8 4NR, England 


\section{MEDICAL BOOKS \\ Prints * Portraits}

Old, Rare,

\section{\& OUT-OF-Print}

\section{America's Largest Stock}

All items are fully catalogued and classified. American and European, dating from the 15th to the 20th centuries particularly classical and unusual works. with emphasis upon history, biography, and specialized medicine.

Lists issued in all fields of medicine.

We are eager to purchase small or large collections.

\section{ARGOSY BOOK STORES}

116 E. 59th St., N.Y., N.Y. 10022, PL.3-4455
F. E.

Whitehart

40 Priestfield Rd.

Forest Hill

London SE23 2RS

01-699 3225

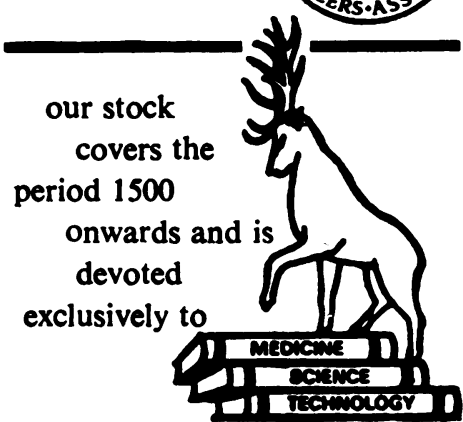

CATALOGUES ISSUED

Normal business hours or by appointment
Rare Books \& Manuscripts in the bistory of

\section{Medicine \& the Sciences}

BOUGHT · SOLD · APPRAISED

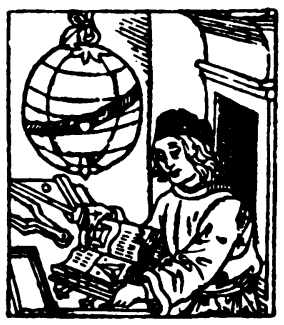

Send for our latest catalogue

Jeremy Norman \& Co., Inc.

$4+2$ POST STREET

SAN FRANCISCO, CALIFORNIA $9+102$

$$
\text { (4I5) } 78 \mathrm{I}-6+02
$$

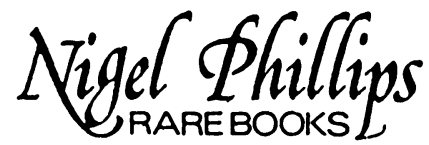

Antiquarian books in the history of medicine and the health sciences.

Please send for my catalogue.

\section{RADCLIFFE SQUARE PUTNEY HILL \\ LONDON SW15 6BL ENGLAND}

Tel: 01-788 2664 